\title{
The Curious Fiction of Treasury Shares*
}

Henry W. Ballantine**

IN AN able series of articles on the California Corporate Securities Act $^{1}, \mathrm{Mr}$. Dahlquist takes polite issue with the view of the writer that the so-called "sale" of "treasury stock" by a corporation is in reality the issue of a new security. The controversy over this point suggests the need of a discussion on principle of the peculiar metaphysical fiction of the law as to treasury shares, ${ }^{2}$ which often puzzles the accountant and facilitates certain financial abuses.

Mr. Dahlquist is concerned with the question whether a "sale" of treasury shares without a permit from the Corporation Commissioner comes within the voiding section of the Act, which provides that "every security issued by any corporation, without a permit", shall be void. He contends that the term "issue" used in section 16, although not defined in the Act, is used in its ordinary sense of an original creation or coming into existence of a security. ${ }^{8}$ He accepts literally, however, the customary fiction as being a fact, that when a corporation acquires from surplus (or not out of capital) one or more shares issued by it that the share contract still continues to exist, if not retired. When the corporation purports to sell a similar number of shares no new contract or security is created, but the purchaser is deemed to be an assignee of the same old share contract that was surrendered to the corporation. He goes on the assumption that the shares "sold" are in some way the same old shares that had previously been validly issued to another, which is the very question in dispute.

Mr. Dahlquist admits that under this theory the requirement of a permit from the Commissioner is "the sole exception to the basic rule that a permit is required under the Act only for an original issue

*Copyright 1946 by Callaghan \& Company.

**Professor of Law, University of Cahfornia.

1 Dahlquist, Regulation and Civil Liability Under the California Corporate Securities Act: II (1946) 34 CALTF. L. REv. 344, 374, 376.

2 Learned Hand, Circuit Court Judge, says in Kirschenbaum v. Comm'r (C. C. A. 2d, 1946) 155 F. (2d) 23, 25: 'The status of 'treasury shares' is in general not made perfectly clear in the books. Some courts treat them as though they were, so to say, in suspended animation-existing, but existing only in a kind of Limbo; other courts treat them as though they were retired."

${ }^{3}$ Dahlquist, op. cil. supra note 1, at 346, 374. 
of securities." But there is, of course, no exception if a disposition of the imaginary treasury shares is not in fact a resale of shares which are still issued, but is a new independent issue of authorized but unissued shares.

In fact the so-called sale of treasury shares is in noway dependent on or connected with the repurchase of the previous shares except insofar as there might otherwise be no authorized but unissued shares available for issue. The purchaser does not ordinarily know whether he is getting "treasury shares" or brand new shares.

To quote now some selections from the author's forthcoming text: ${ }^{4}$

Treasury shares are indeed a masterpiece of legal magic, the creation of something out of nothing. They are no longer outstanding shares in the hands of a holder. They are not outstanding because the obligor has become the owner of the "obligation" as in the case of reacquired bonds.

As Hills has well said: ${ }^{\circ}$

"Can a corporation have 'ownership' in itself? Can it possess 'legal rights and powers' or 'legal property' or 'property' derived solely from itself? Corporation law holds it cannot. Treasury shares do not have voting rights, dividend rights or distribution rights on liquidation, so what rights, if any, remain? Perhaps the 'right' of the corporation to reissue its treasury shares for a valuable consideration if its charter law permits-but that is a mere incident of incorporation which is applicable to unissued as well as issued shares. Treasury shares are not a corporate 'asset' and cannot be considered as an asset in computing net assets or surplus available for dividends or share purchases."

The only difference between reacquired shares held " in the treasury" and those which have been retired is that the first may be resold by the corporation for what they will bring on the market, while the retired shares have disappeared and it becomes a question of original issue at par. Treasury shares carry no voting rights or rights as to dividends or distributions. Their existence as issued shares is a pure fiction, a figure of speech to explain certain special rules and privi-

4 Batrantine on CoRporations (Rev. ed. 1946) \& 260. In this discussion the writer has drawn on certain portions of the forthcoming revised edition of his 1927 work on Corporations (now in press), which is to be distinguished from BaLLANTINE and STERLing, Calmornia Corporation laws (1938). The latter is now out of print and no new edition is contemplated for a year or more.

* Kemp v. Levinger (1934) 162 Va. 685, 700, 174 S. E. 820, 826. See 1 Davies, Orio CoRPoRATION LAW (1942) 709, 711, 712.

${ }^{6}$ Hills, Federal Taxation v. Corporation Law (1937) 12 Wus. L. Rev. 280, 299. 
leges as to their reissue. A share of stock is simply a unit of interest in the corporate enterprise arising from a contract. ${ }^{7}$ When the holder of a share surrenders his rights to the corporation it is obvious that the contract is in reality terminated. In cases where the vote or assent of a majority of the shareholders is required or a given proportion of the shares is spoken of, it must be understood to mean shares which are issued and outstanding and which may be voted. ${ }^{8}$

The truth is that "treasury stock" is merely authorized stock which may be reissued as fully paid without some of the restrictions upon an original issue of shares as to consideration and as to preemptive rights, if any. While often treated by accountants as an asset, such treatment is for record purposes only, not to evaluate the "asset". It no more represents a present asset than authorized but unissued shares, being merely the opportunity to acquire new assets if anyone wishes to buy the shares. ${ }^{0}$ If the company becomes insolvent, no such opportunity will arise and the treasury stock will represent nothing of value to the creditor. ${ }^{10}$

If shares in corporation $A$ are purchased or held by corporation $B$, the shares of which are wholly owned or controlled by $A$, it would seem that such shares are not to be regarded as in legal contemplation treasury shares of the parent. ${ }^{11}$ But they will not carry voting rights because the voting power would be controlled by the management of the parent and this would be indirect voting by the parent. ${ }^{12}$

When so-called treasury shares are sold by the corporation it is (by a fiction) regarded as if the shares issued to the purchaser were the old shares and as if the corporation had merely been an intermediate transferee. In reality the old contract was extinguished by merger and the new shares are new units of interest created in their place. ${ }^{13}$ The principal use of this fiction of already issued shares has

' Ballintine, op. cit. supra note 4, c. XIII, \$198.

8 Market St. Ry. v. Hellman (1895) 109 Cal. 571, 42 Pac. 225; Italo Petroleum Corp. v. Producers Oil Corp. (1934) 20 Del. Ch. 283, 174 Atl. 276; Note (1934) 90 A. L. R. 315, 318.

${ }^{9}$ Borg v. International Silver Co. (C. C. A. 2d, 1925) 11 F. (2d) 147.

10 Glenn, Treasury Stock (1929) 15 VA. L. REv. 625, 637.

11 Golden State Theatre \& Realty Corp. v. Comm'r (C. C. A. 9th, 1942) 125 F. (2d) 641; Vanderlip v. Los Molinos Land Co. (1943) 56 Cal. App. (2d) 747, 755, 133 P. (2d) 467, 472; Lawrence v. I. N. Parlier Estate Co. (1940) 15 Cal. (2d) 220, 229, 100 P. (2d) 765, 770; Italo Petroleum Corp. v. Producers Oil Corp. (1934) 20 Del. Ch. 283, 174 Atl. 276.

12 Lawrence v. I. N. Parlier Estate Co.; Italo Petroleum Corp. v. Producers Oil Corp., both supra note 11 .

131 Morawetz, Corporations (2d ed. 1886) § 114. 
been to get around the wooden requirement of some states, that par value shares must be issued at par at all times, which is an arbitrary and unreasonable rule relaxed by the California General Corporation Law. ${ }^{14}$ The issue of all the shares has often been made to a promoter as being fully paid for a somewhat fictitious consideration, in the process of stock watering, and then a large part of these fully paid shares has been donated back to the corporation for resale at a discount. ${ }^{15}$ Another common use of the fiction is to facilitate operations by a corporation and its management in speculating in its own shares and to enable the corporation to display a fictitious surplus which has enabled it to get around limitations upon dividends and upon the purchase of its own shares. It would clear away a great deal of needless mystification about treasury shares to treat all reacquired shares as automatically retired and restored to the status of authorized and unissued shares.

The fictitious nature of treasury shares has led to much bewilderment in accounting procedure as well as in other topics. ${ }^{16}$ Formerly many corporations carried their treasury shares as an asset although they represent in reality a withdrawal of assets like a dividend. This practice is now discredited. Many corporations still show treasury shares as a deduction from "capital stock" or capital liability. As Hills says: ${ }^{17}$

"To carry shares of any class as an apparent deduction from stated capital is necessarily (a) a misrepresentation that surplus has not been reduced, or (b) in case there is not sufficient surplus to absorb the reduction, an admission of an illegal reduction of stated capital, or (c) a representation that stated capital has been legally reduced. A requirement that treasury shares be purchased only from surplus is a requirement that such shares be not carried as an asset or as a deduction from stated capital. Any counteracting entries which maintain the balance existing prior to the purchase, such as the addition of an asset or the reduction of the 'capital stock liability,' violate the plain intent and expression of the law."

It is unfortunate that accountants by reason of erroneous concepts of treasury shares should often misinterpret by their entries in

14 CAL. Crv. Code $\$ 299$.

15 See Ballantme, op. cit. supra note 4, c. XXII, $\$ \S 346,347$; c. XXIII, $\$ 359$.

16 Balrantine, op. cit. supra note $4,538,617,618$. See Dahlquist, op. cit. supra note 1 , at $374, \mathrm{n} .143$.

17 Hills, Model Corporation Act (1935) 48 HARV. L. REv. 1334, 1342. See Nemmers, The Power of a Corporation to Purchase its Oum Stock (1942) Wrs. L. Rev. 161, 183-191. 
balance sheets the financial and legal effect of transactions by corporations in their own shares. An honest method of presentation is to show treasury shares simply as a deduction from the number of shares outstanding without any entry in the asset column or liability' column of the balance sheet. The surplus will stand diminished by the amount of the purchase price, as in case of a withdrawal by way of a dividend..$^{18}$

The purchase by a corporation of its own shares necessarily reduces the net assets and should be indicated as reducing surplus, at least temporarily. The accounting treatment of treasury shares is one of the most puzzling and controversial practices in corporate accounting. But it is simple enough if the financial and legal effect of the purchase can be understood. Thus far administrative rules of the Securities and Exchange Commission and other regulatory commissions have not helped to clarify the matter.

It is held that the corporation may reissue and sell these so-called treasury shares without increasing legal capital as an original issue would do. The reason for this distinction is that the corporation has already received a capital contribution and created a stated capital "liability" in respect to the shares so issued and acquired, which was not reduced upon acquisition of the shares. Upon their reissue these shares do not increase the capital liability. ${ }^{18}$

Statutory definitions for the computation of stated capital vary somewhat in the different states. Thus it is sometimes measured by the purported contributions to capital of all shares which have been issued froin time to time, thus including treasury shares as well as outstanding shares and even retired shares; ${ }^{20}$ but sometimes including only the issued or the outstanding shares. ${ }^{21}$

18 As to various methods of accounting for treasury shares and the financial effect of the transaction on capital and surplus, see BaLIANTINE and STRerIING, op. cit. stipra note 4, at 232-235; 1 DAvIEs, op. cit. supra note 5, at 711 (with citation of many articles); Dodd and Barer, CASes on Bustness Assoctattons (1940) 750-753; Katz, Accounting Procedure in Corporate Distributions (1941) 89 U. of PA. L. REv. 764, 771, 772 ; Kripke, Accountants Financial Statements and Fact-Finding in the Law of Corporate Regulations (1941) 50 Yale L. J. 1180, 1184; (1942) 20 ChI-Kent Rev. 115, 129; (1941) 25 MnNN. L. Rev. 744, 774; (1935) 13 TEx. L. Rev. 442, 454.

18 Grazada and Katz, Accodntrng in Law Practice (2d ed. 1938) §§ 87-91; Hills, op. cit. supra note 17, at 1373-1376; Hills, Stated Capital and Treasury Shares (1934) $57 \mathrm{~J}$. Accountancy 202, 214; Katz, op. cit. supra note 18, at 779.

20 CAL. CIv. CODE $\S 300 \mathrm{~b}$.

21 Under the Ohio General Corporation Act [OHIo CoDE (Baldwin 1940) §8623$37(8)$ ] treasury shares are "deemed" outstanding for the purpose of determining the stated capital, another fiction to fit a poor definition of stated capital. 
If treasury shares are reissued after purchase from earned surplus, which was thereby reduced, the proceeds do not go to reinstate the former earned surplus. ${ }^{22}$ The proceeds do not represent profits, but a new investment by the purchaser. Any increase in net worth over legal capital so derived must be attributed to paid-in surplus, not to accumulated earnings.

The reissue of treasury shares by a corporation as a purported stock dividend cannot be approved, since there is no consideration for the issue, no capitalization of surplus. ${ }^{23}$ The stated capital was not reduced when the treasury shares were acquired, and is not increased upon their reissue. Such a so-called stock dividend is simply stock watering which does not represent capitalization of surplus, but only a prior disbursement of the purchase price to a former shareholder. ${ }^{24}$ The withdrawal of assets in favor of a former shareholder is no basis for a free distribution of additional shares to the remaining shareholders; to call it a "dividend", either in stock or in property, is entirely misleading. ${ }^{25}$

\section{IN CONCLUSION}

The California General Corporation Law codifies the customary fictions as to the theoretical existence of treasury shares for certain limited purposes only (California Civil Code sections 342a, 342b), but these provisions were not intended and do not purport to have any bearing on the Corporate Securities Act.

Mr. Dahlquist contends that a sale of treasury shares without a permit would be "illegal", "possibly even a crime", ${ }^{26}$ but he contends that the security sold would not be void, as in all other cases where a permit is required, and only the immediate purchaser could recover the price from the corporation. His argument is that the legislature, by the use of the word "issue" in section 16, deliberately excluded the "sale" of treasury shares from this voiding section, although a

22 Cat. Civ. Code \$ 342b. Batiantine and Sterding, op. cit. supra note 4, at 184; 1 Davies, op. cit. supra note 5, at 712, n. 41 (surplus arising from the sale of treasury shares is to be treated as capital surplus). Cf. Katz, op. cit. supra note 18, at 787 .

23 By section $346 \mathrm{a}$ of the California Civil Code the capitalization of surplus is made the exclusive basis of declaring dividends paid in the corporation's own shares. See also 11 Fretcher, Crc. Corps. (Perm. ed. 1932) \$ 5362.

24 Bass v. Comm'r (C. C. A. 1st, 1942) 129 F. (2d) 300, 309; 1 Daviss, op. cit. supra note 5, at 712; Marple, Caprtax Surplus and Corporate Net Worte (1936) 74, 75.

25 The treasury authorities have attempted to treat dividends in treasury shares as a property dividend, which is clearly unsound. 1 Mertens, LAw of Federar Incosre TAXATION (1942) §9.117, p. 656 .

26 Dahlquist, op. cit. suppra note 1 , at 375 . 
permit is required. A more reasonable construction of sections 3 and 16 is that the sale of treasury shares is treated as the issue of a new security, as in fact it is, subject to the same penalty as other issues.

Mr. Dahlquist also contends that while a corporation must obtain a new permit before it can sell reacquired bonds or obligations, yet the "sale" of such bonds to a new investor without a permit would not render the bonds void. ${ }^{27}$ The main reason assigned is that the paper on which the bond is printed or engraved is itself the obligation, and not merely evidence of it. It is indeed the language of the old books that "the existence of the instrument in proper form involves the continued existence of the obligation." 28

But if the corporation purchases some of its own bonds, even if it does not surrender them to the indenture trustee for cancellation, but holds the documents "in its treasury", it certainly accomplishes a reduction of its liabilities to the extent of their face value. The balance sheet should show the bonded indebtedness reduced by the par value of the repurchased bonds. ${ }^{20}$

The corporation has a right to "resell" these reacquired bonds, in the absence of contract to the contrary. ${ }^{30}$ But the realistic explanation of this is that although the old obligation was extinguished by the union of the right and the duty in the corporation, ${ }^{31}$ the old instrument may be used to evidence the issue of a new security for a loan by a new lender upon the same terms as the old, subject to the voiding section of the Securities Act.

$2 \pi$ Dablquist, op. cit. supra note 1 , at 379.

281 WIITISTON, Contracts (Rev.ed. 1936) § 205; 6 ibid. § 1890.

29 Sunley and Carter, Corporation Accounting (1945) 228-230.

306 FLETCHER, op. cit. suppra note $23, \S 2729$.

31 See Restatement, Contracts (1932) §432(1). 